\title{
AN INSTITUTIONAL REINFORCEMENT MODEL FOR THE PROTECTION OF MANGROVES SUSTAINABLE ECOTOURISM IN INDONESIA
}

\author{
Pudji PURWANTI* \\ Universitas Brawijaya, Faculty of Fisheries and Marine Science, Indonesia, e-mail: pudjipurwanti@ub.ac.id \\ Mochammad FATTAH \\ Universitas Brawijaya, Faculty of Fisheries and Marine Science, Indonesia, e-mail: mochammadfattah@ub.ac.id
}

Vika Annisa QURRATA

Universitas Negeri Malang, Faculty of Economics, Indonesia, e-mail: vika.annisa.fe@um.ac.id

\section{Bagus Shandy NARMADITYA}

Universitas Negeri Malang, Faculty of Economics, Indonesia, e-mail: bagus.shandy.fe@um.ac.id

\begin{abstract}
Citation: Purwanti, P., Fattah, M., Qurrata, V.A., \& Narmaditya, B.S. (2021). AN INSTITUTIONAL REINFORCEMENT MODEL FOR THE PROTECTION OF MANGROVES SUSTAINABLE ECOTOURISM IN INDONESIA. GeoJournal of Tourism and Geosites, 35(2), 471-479. https://doi.org/10.30892/gtg.35227-674
\end{abstract}

\begin{abstract}
This study aims at examining the sustainability of mangrove ecotourism at Cengkrong Mangroves Ecotourism in Indonesia. A quantitative approach was adopted to capture the complexity of the phenomenon. The study was conducted in an area with most mangroves in Indonesia, including Cengkrong Ecotourism in Trenggalek, East Java. Sustainability is achieved when each stakeholder makes a positive contribution to others in ecology, economy, social, institutional and law enforcement, and technology. Using multi-dimensional scaling and Monte Carlo approach, the findings of this study indicate that Cengkrong mangrove ecotourism is classified as "sustainable" (76.20\%). The highest dimension is ecology due to the minimum level of pollution in the area. Even Cengkrong beach mangrove is a tourist destination which is potentially polluted by the tourist; however, the area is not densely populated. Nevertheless, amongst the other indicator, social is the lowest (67.95\%).
\end{abstract}

Key words: Ecotourism development; Institutional reinforcement model; Mangroves reforestation; Rap Ecotourism analysis; Sustainable ecotourism

\section{INTRODUCTION}

Indonesia is the sixth country with the largest mangrove area in the world behind Malaysia, Brazil, Australia, Mexico, and Nigeria which providing nearly 23 percent of global mangrove cover (Hamilton and Casey, 2016). One of Indonesia's most extensive mangrove forests is Cengkrong Beach in Trenggalek of East Java (Purwanti et al., 2017a). Mangroves are an essential ecosystem in providing a wide range of goods and services that significantly promote to the society (Santos et al., 2017). In addition to provide raw materials, mangroves forest also presents as a breeding ground for various types of fish, crustaceans, and mollusks, thus preserving biodiversity and demonstrating their interdependence to the nearby ecosystems such as seagrass beds and coral reefs (Mumby et al., 2004; Barbier et al., 2011).

This situation is beneficial to the local communities in enhancing the income sources (Satyanarayana et al., 2013). The underlying reason is that the mangrove ecosystem has a variety of potentials in terms of biological wealth, such as biology, economy, and tourism (Turisno et al., 2018). In addition to these advantages, mangroves also promote various indirect advantages in the term of coastal protection and wave attenuation, in the event of physical effects such as tsunamis (Feagin et al., 2010). In the wider perspectives, mangroves are the link between terrestrial and marine ecosystems. It also plays an essential role in regulating nutrient cycles and carbon storage (Donato et al., 2011). Despite mangroves have provided beneficial for human life, however, it is threatened by various anthropogenic activities. Mangrove cover has escalated remarkably since 1970 (Giri et al., 2011; Richards and Friess, 2016), and mangrove forests remain under pressure from clearcutting, land-use change, hydrological alterations, chemical pollution and climate change (Lee et al., 2014).

Mangrove Forest Pancer Cengkrong is located at coordinates $8^{\circ} 17^{\prime} 52^{\prime \prime} \mathrm{S} 111^{\circ} 42^{\prime} 25^{\prime \prime} \mathrm{E}$ in Trenggalek district, East Java province of Indonesia, located 500 meters from the coast of the Cengkrong area which has a rainfall of $3.094 \mathrm{~mm}$ and an average temperature of $23^{\circ} \mathrm{C}$ (Figure. 1). This area suffered severe damages as a result of cleared land and conversion into coconut plantations. In 2008, the local Maritime and Fisheries Department undertook a hectare (ha) restoration project and formed a Community Monitoring Group called Kejung Samudra to conserve mangrove forests at Cengkrong Beach. The area mangrove forests has increased every year due to the community watch group conducts monitoring and reforestation every year (Nguyen 
et al., 2016). In the next three years the trees grew nearly tenfold. In 2012, the local Maritime and Fisheries Department introduced the concept of a mangrove forest education tourism by building a wooden bridge (Purwanti et al., 2017a). They also provide boat donations to make tourists enjoy the attractions by exploring the mangrove forest to the Cengkrong estuary.

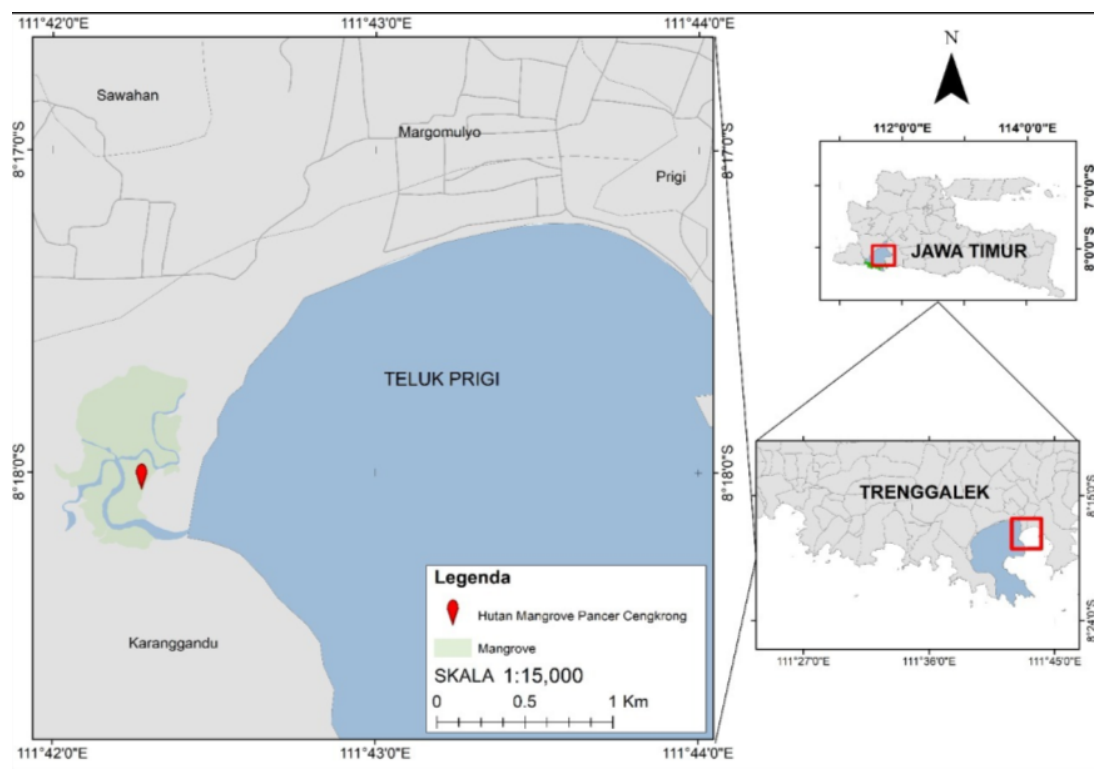

Figure 1. Sketch of Mangrove Forest Pancer

Kejung Samudra, as a community monitoring group, not only succeeded in strengthening the mangrove area into an ecotourism area but also became a universal adapter between the people of the Prigi Bay and the local government. Unfortunately, while various existing institutions have not fully supported Kejung Samudra, there are even indications of a struggle over the management and utilization of resources (Purwanti et al., 2017c). The basic reason is that the ecotourism-based community is a dominant form of tourism in developing countries, where the local communities are involved in the management (Mitchell and Faal, 2007). Rapid tourism growth affects tourist arrivals and benefits the local economy, but excessive tourism activities can reduce the quality of tourism itself (Lin and Yang, 2016). For example, in some mangrove forests in Indonesia called Bontang, the management of ecotourism activities did not follow the requirements of sustainability (Anggoro et al., 2019). Ecotourism activities have significant advantages for education, protection, and conservation of mangrove forests (Friess, 2017). Preservation of mangrove forests must involve local communities as they require the existence of sustainable mangrove forests to meet their needs and have the local wisdom in preserving mangrove forests (Eddy et al., 2016). Sustainable mangrove management requires ecotourism and involves local communities. Hence, the development of ecotourism needs to consider the sustainability of natural resources. In Cengkrong Beach, mangrove reforestation is successful and profitable for tourism destinations due to the excellent management of Kejung Samudra. Notwithstanding, the rapid growth of mangrove tourism in Cengkrong Beach has raised fears of overexploitation. As a consequence, it will reduce the quality of mangrove forests as a place of education. In the long term, it does not rule out the possibility of damage to mangrove forests in Cengkrong Beach. Furthermore, many local government institutions do not fully support community monitoring groups; there are even some indications of a power struggle in the management and utilization of resources between the two parties (Purwanti et al., 2017b). Dealing with sustainable mangrove management has been a global challenge primarily related to institutional conflicts (Ghazoul, 2007). In this context, social-ecological assessments, particularly in institutional reinforcement, serves as a vital tool for coastal management, as it enables them to translate socialecological information into policy decisions. This decision-making process connects mangrove-dependent communities and managers (Young et al., 2018). Numerous antecedent studies on sustainable ecotourism development have examined among scholars (Carandang et al., 2013; Cormier-Salem and Panfili, 2016; Thompson et al., 2018). A great deal of previous studies has focused on economic valuation in mangrove management. In contrast, other studies by Martinez-Espinosa et al. (2020) noted that collaborative management at Mangrove Forest Reserve is very much needed to maintain sustainability. However, there is minor attention of scholars that examining sustainable ecotourism mangrove by using the institutional reinforcement model. Therefore, the purpose of this study is two folds: first, this study provides insight into strengthening the social dimension, which requires institutional reinforcement in mangrove ecotourism, e.g., establish collaborative management among all stakeholders in the distribution of benefits. Second, this study evaluates the sustainability of mangrove ecotourism at Cengkrong Mangroves Ecotourism in Indonesia using Multi-Dimensional Scaling Rap-ecotourism (MDSR-ecotourism) in 2019 and to propose the model which can be maintaining and improving the sustainability.

\section{MATERIALS AND METHODS}

\section{Description of the study area and context}

A quantitative approach was adopted to capture the complexity of the phenomenon. The area study was chosen for its most mangrove in Indonesia, including Cengkrong Ecotourism in Karanggandu village of Trenggalek, East Java. The data of this study were collected through questionnaires with scale ranging from 0 to 10 by conducting in-depth interviews with stakeholders, and Focus Group Discussions (FGD) at the village levels. The questionnaires are needed to provide an assessment of the sustainability of the ecosystem in each of its dimensions and indicators. This study used purposive sampling on the basis of determining experts to be respondents using three criteria: being a mangrove ecotourism manager, being a resident who knows the condition of mangrove ecotourism, having experience in planting, maintaining and monitoring mangrove activities. Using Rap-ecotourism, scores can be given by experts, individuals, communities according to the number of research needs (Pitcher and Preikshot, 2001). The participants in this study were recruited from stakeholders with a total of 17 people which meets the criteria. Stakeholders consist of community watch groups, villagers, and government agencies 
represented by the forestry department and local government. Furthermore, the data were analysed using Rap-ecotourism, which is the adjustment method of Rapfish (Rapid Appraisal of Fisheries) (Pitcher and Preikshot, 2001; Pitcher et al., 2013).

\section{Variables measurement}

The sustainability aspects are determined by five dimensions, namely ecology, economics, social, law, and institutional (Table 1). There are several stages in the analysis data. First, Multi-Dimensional Scaling (MDS), the ordination technique is analyzed with MDS to determine the position of good and bad points. Meanwhile, Monte Carlo (MC) aims to evaluate the impact of random errors made in estimating the ordination value used; Leverage, to find out the sensitive attributes of each sustainability dimensions used. Besides, Rap-ecotourism analysis is apply using software tool R. The sustainability index of mangrove forest ecosystem management in the data analysis is group into four categories of sustainability status, which provided in Table 2.

Table 1. Multidimensional scaling dimensions and indicators

\begin{tabular}{|c|l|l|l|l|l|}
\hline \multirow{2}{*}{ No. } & \multicolumn{1}{|c|}{ Ecology } & \multicolumn{1}{|c|}{ Economy } & \multicolumn{1}{c|}{ Social } & \multicolumn{1}{c|}{ Law and Institution } & \multicolumn{1}{c|}{ Technology } \\
\hline 1 & Support system & Counselling and training & Education Facilities & Local culture & Water supply technology \\
\hline 2 & Conservation zone & Utilization Zone & Ecosystem Damage & Government Policy & $\begin{array}{l}\text { Electrical supply } \\
\text { technology }\end{array}$ \\
\hline 3 & Habitat Changes & Production Inventory & $\begin{array}{l}\text { Knowledge and } \\
\text { Perception }\end{array}$ & Officer & $\begin{array}{l}\text { Technology for seed } \\
\text { nurseries }\end{array}$ \\
\hline 4 & $\begin{array}{l}\text { The diversity of } \\
\text { organism }\end{array}$ & $\begin{array}{l}\text { The opportunity of } \\
\text { livelihood }\end{array}$ & Participation & $\begin{array}{l}\text { The punishment and law } \\
\text { enforcement }\end{array}$ & $\begin{array}{l}\text { Waste management } \\
\text { technology }\end{array}$ \\
\hline 5 & Environmental pollution & Income & Awareness & $\begin{array}{l}\text { The management } \\
\text { planning }\end{array}$ & $\begin{array}{l}\text { Liquid waste } \\
\text { management technology }\end{array}$ \\
\hline 6 & Erosion barrier & Conflict Mechanism & $\begin{array}{l}\text { The obedience and } \\
\text { compliance }\end{array}$ & $\begin{array}{l}\text { Environment } \\
\text { friendly technology }\end{array}$ \\
\hline 7 & $\begin{array}{l}\text { The species diversity of } \\
\text { mangrove }\end{array}$ & $\begin{array}{l}\text { The management } \\
\text { mechanisms and rules }\end{array}$ & $\begin{array}{l}\text { communication and } \\
\text { coordination }\end{array}$ & \\
\hline 8 & $\begin{array}{l}\text { the availability of } \\
\text { mangrove seeds }\end{array}$ & $\begin{array}{l}\text { The institution } \\
\text { participation }\end{array}$ & \\
\hline 9 & $\begin{array}{l}\text { The suitability of } \\
\text { mangrove area }\end{array}$ & & & & \\
\hline
\end{tabular}

Table 2. Sustainability status

\begin{tabular}{|l|l|}
\hline \multicolumn{1}{|c|}{ Index } & \multicolumn{1}{c|}{ Category } \\
\hline $0-25$ & Unsustainable \\
\hline $25.5-50$ & Insufficient sustainable \\
\hline $50.5-75$ & Moderate sustainable \\
\hline $75.5-100$ & Sustainable \\
\hline
\end{tabular}

\section{RESULTS AND DISCUSSION}

The Sustainability of Ecotourism Management in Indonesia

Ecotourism is a form of sustainable tourism in the natural and cultural heritage area. Ecotourism allows tourists to see the life of local communities, conserved natural resources, the culture, and indigenous knowledge, daily practices, environmental education, and ethics. The implementation of ecotourism must be in line with the fundamental principles that aim to reduce adverse environmental impacts.

Besides, ecotourism should contribute to the economic benefits of conservation and community well-being. It also has a positive effect on owners and tourists, enhancing local community empowerment, national culture, socio-economic and political characteristics (Das and Chatterjee, 2015; Ghorbani et al., 2015). By looking at sustainable tourism, we encompass a wide range of tourism stakeholders that play critical roles in creating a sustainable tourism ecosystem. The area mangrove forests has increased every year due to the community watch group conducts monitoring and reforestation (Nguyen et al., 2016).

The area of mangrove in 2015 to 2018 had increased to more than 50 percent from 101.79 to 164.43 ha. Behind the fact for this movement is that the Cengkrong is a famous area for mangrove forest ecotourism, then the mangrove planting is carried out every year. It is in line with the implementation of the Community-Based Conservation (CBC) approach through adaptive co-management between local communities, government agencies, and NGOs as recommendations to develop mangrove conservation in Malaysia. This awareness came after the Tsunami disaster in 2004 (Abdullah et., 2014). Not only in Malaysia and in the Koh-Mak community in Southern Thailand, but the key to sustainable tourism development is also the participation and empowerment of local communities (Suwanno et al., 2017).

The impact of mangrove replanting and managing under the community monitoring group felt to start in 2012 due to the construction of a wooden bridge by the Department of Marine and Fisheries; then, tourists start visiting to enjoy the mangrove plants. In addition, they also provide boat donations to make tourists enjoy the attractions by exploring the mangrove forest to the Cengkrong estuary. Kejung Samudra, as a community monitoring group, not only succeeded in strengthening the mangrove area into an ecotourism area but also became a universal adapter between the people of the Prigi Bay and the local government. Unfortunately, while various existing institutions have not fully supported Kejung Samudra, there are even indications of a struggle over the management and utilization of resources (Purwanti et al., 2017c).

The ecotourism-based community is a dominant form of tourism in developing countries, where the local communities are involved in the management (Mitchell and Faal, 2007). Community-based natural resources management practices have identified the resident community as an essential player in conserving natural resources. It highlights the importance of community ownership and community livelihoods in the conservation and management of natural areas and resources (Stone and Rogerson, 2015). This circumstance has not reflected yet in Cengkrong Beach. Nevertheless, this ecotourism brings economic benefits in the form of parking services, animal feeding services, bathroom services, umbrella/hat rental, food and 
beverage stalls, and grilled fish stalls (Purwanti et al., 2017a). This economic benefit is the different factors affecting the willingness to pay ( $25 \%$ level), including education, income, and information (Carandang et al., 2013). It supports the concept of forest-based tourism, which is a useful tool in Bangladesh for the conservation of forest resources and sustainable biodiversity, which can generate income in the form of ecotourism (Alam et al., 2010).

The communities also obtain profit from productive activities for capturing mangrove crabs and fishing. The community watch group develops activities for mangrove crab farming, Annadara sp mussels, mangrove tree nurseries, and manufacture of mangrove syrup. In the long run, the financial calculation of the business of mangrove crab farming, the cultivation of Annadara sp mussels, mangrove tree nurseries, and the manufacture of mangrove syrup have an excellent profit value and can be developed (Purwanti et al., 2017b). Therefore, the index value of ecological, economic, social, legal, and institutional sustainability, and technology from the MDS Rap-ecotourism analysis shows that in the management of Cengkrong coastal mangrove ecotourism in a sequence of $83.19 \%$ (sustainable), $73.46 \%$ (moderately sustainable), 67.95\% (moderately sustainable), $81.34 \%$ (sustainable) and $75.07 \%$ (sustainable) (Figure 2). Multidimensionally, the sustainability status of Cengkrong beach mangrove ecotourism management in the sustainable category is $76.20 \%$ to maintain or improve the status of need to pay attention to sensitive indicators. The figure is obtained from the sum of all dimensions, then divided by five dimensions. Table 2 shows that the mangrove ecosystem is multidimensional in a sustainable status. However, this value is still in low rank, even it is close to $75 \%$. Then, it is still necessary to make improvements in mangrove forest management.

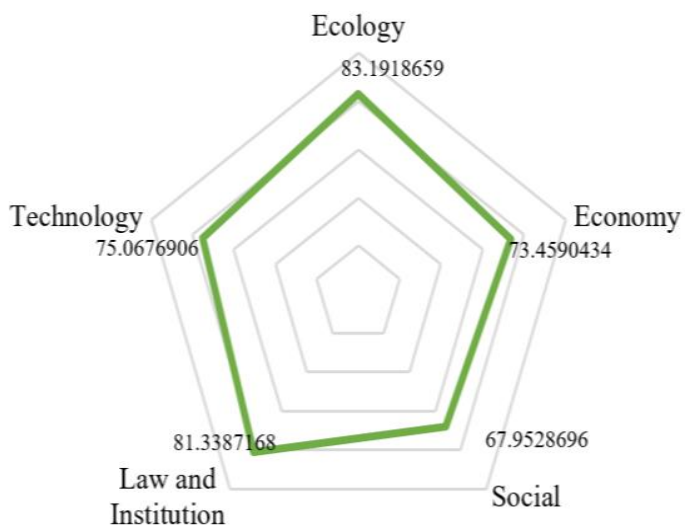

\begin{tabular}{|c|c|c|c|c|c|}
\hline $\begin{array}{c}\text { Sustainability } \\
\text { index }\end{array}$ & Ecology & Economy & Social & $\begin{array}{c}\text { Law and } \\
\text { Institution }\end{array}$ & Technology \\
\hline $\begin{array}{c}\text { MDS } \\
\text { (Multidimensional } \\
\text { Scaling) }\end{array}$ & 83.1918659 & 73.4590434 & 67.9528696 & 81.3387168 & 75.0676906 \\
\hline $\begin{array}{c}\text { MC } \\
\text { (Monte Carlo) }\end{array}$ & 83.1918529 & 73.4590412 & 67.9528647 & 81.3387059 & 75.0677000 \\
\hline Difference & 0.00001294 & 0.00000218 & 0.00000492 & 0.00001089 & 0.00000942 \\
\hline
\end{tabular}

Figure 2. Kite diagram of a multidimensional sustainability index Cengkrong beach mangrove ecotourism

Using Monte Carlo, it is proven that the little difference in the value of the sustainability index between the analysis results from MDS and MC shows the effect of errors can be avoided (Wibowo et al., 2015). The MDS value compared to the MC resulted in a low difference value. This indicates that the MDS value has a high level of confidence because of the minimum procedural errors or understanding of indicators and the variation in scoring, which can be seen in Table 3 .

\section{Sensitivity sustainability of Cengkrong Beach ecotourism management}

The sensitivity to the sustainability of mangrove forest management from each dimension indicators using leverage analysis (Karlina et al., 2016). As shown in Figure 3, the indicators that need to be considered in the management of Cengkrong coastal mangrove ecotourism in ecological dimensions are the pollution of mangrove ecosystems, the diversity of flora and fauna populations, and the ability of mangroves to resist abrasion. Cengkrong beach mangrove is a tourist destination, so the potential for liquid and solid waste pollution is a factor to be aware. This is due to the fact that if there is an irresponsible tourist, it will cause pollution. Cengkrong coastal mangrove area was initially damaged; however, with the increasing public awareness, mangrove forests will become more sustainable. The area is not densely populated; therefore, no pollution is caused by excess industrial waste. However, organic residues in the household can help the growth of mangroves or fertile soil. Cengkrong beach mangroves preservation works to prevent stream erosion in the middle of the mangrove area, while the coastline distance with the mangrove is relatively far. The stakeholders are preserving the mangrove ecosystem due to that ecological dimension is related to their economic growth.

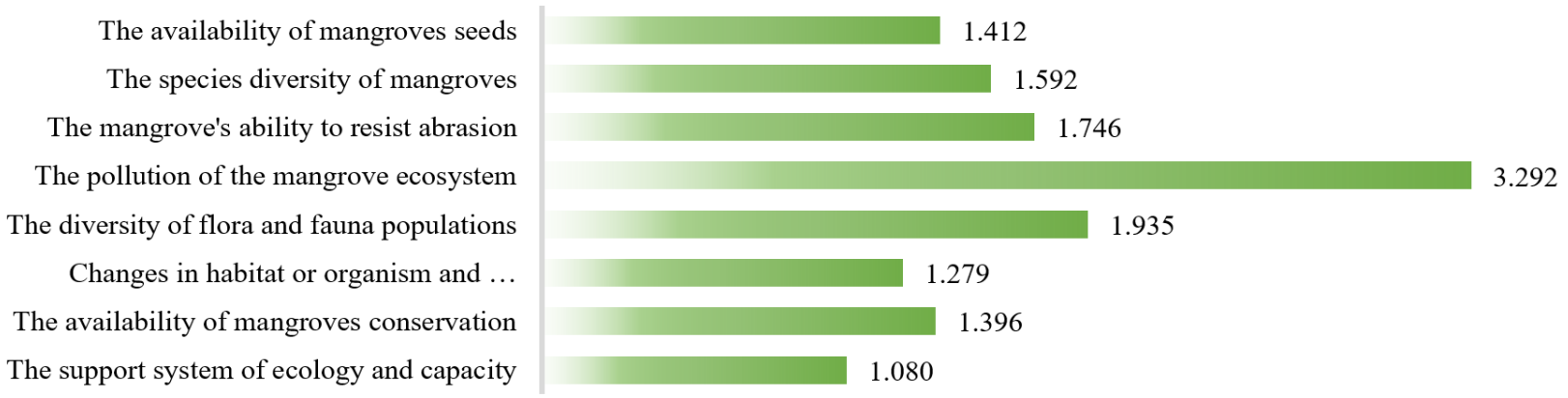

Figure 3. Leverage scoring for ecological dimension 
The analysis results in the economic dimension perspective are presented in Figure 4. In general, the most pressing concern is the production inventory, while the lowest score is the income value-added from the mangrove ecosystem. The community's main interests in the economic dimensions are inventory of products from mangrove activities, employment opportunities, assisting and training in mangrove ecosystems. The recording of the use of flora and fauna obtained by Cengkrong beach ecotourism must be conducted to understand the value of benefits and to supervise it. Then it will not damage the ecosystem. The job opportunities from mangrove sustainability have an impact on the community or management team. Therefore, it will be non-destructive activities on mangroves. Alternative development of employment opportunities can be through assisting and training in mangrove utilization. The excellent condition of the mangrove forest ecosystem has an impact on employment opportunities for the community (Purwanti et al., 2018). The economic benefits enjoyed by the community watch group include mangrove tourism management, mangrove crab farming, shellfish cultivation, and mangrove nursery business (Purwanti et al., 2017b). The establishment of mangrove-based program socialization activities received quite a response from the community. They are enthusiastic and have a will to develop mangrove preparations. This activity is intended to enhance the awareness of participants dealing with the economic benefits of mangroves. Furthermore, this mangrove fruit can be used as flour, which can be used as a necessary ingredient of brownies and steamed bread (Purwanti et al., 2017c). Mangroves are not only for food but can also be used as keychains (Sueb et al., 2020).

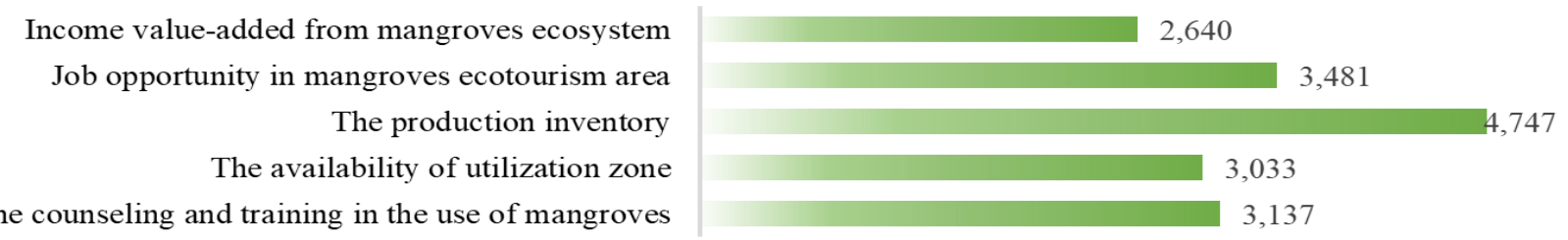

Figure 4. Leverage scoring for economic dimension

Figure 5 depicts the levering score for the social dimension. Sensitive indicators that are the priorities attention to the social dimension are community awareness, knowledge, and conflict resolution mechanisms. From the figure, it is known that public awareness to conserve mangrove ecosystems is the most sensitive indicator in the social dimension. This finding is in line with previous studies that public awareness of the function and benefits of mangrove forest ecosystems has a positive effect on improving mangrove forest conservation (Muluk, 2010). Meanwhile, the lack of public knowledge and awareness about the functions and roles of mangrove vegetation, and the damage of mangrove ecosystems are affected by land conversion into settlements, markets, and terminals in inadequate management of mangrove ecosystems (Rudianto et al., 2020). The knowledge of community about mangrove forests will increase if the government and universities provide assisting to them so that it affects the increase in participation in the preservation of mangrove forests (Cesario et al., 2015). Besides, coastal community groups understand the benefits of mangrove forests as a buffer for living ecosystems so that they try to preserve sustainability (Aulia et al, 2020). Moreover, community-based supports sustainable use of marine resources and offers an entry point for low-resource coastal communities to take part in the blue economy (Phelan et al., 2020).

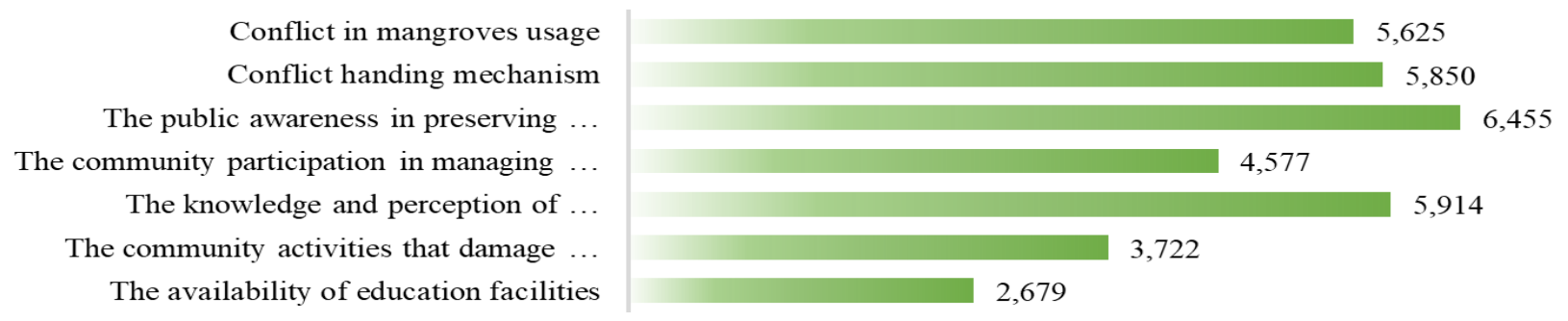

Figure 5. Leverage scoring for social dimension

Figure 6 presents the summary analysis of levering scoring for law and institutional dimensions. It can be seen from the data in the figure that the legal and developmental dimensions are punished, and law enforcement, mangrove management planning, and institutional activeness of mangrove management are sensitive indicators that invited priority attention. The conflicts of interest in not only between institutions due to differences in interests between mangrove forest managers and local governments but also for the economic benefits of mangrove forests and conservations (Sodikin, 2014). Proper management and attention to the balance of mangrove ecosystems to minimize mangrove forest degradation and conflicts between the utilization of mangrove resources (Agusalim and Hartoni, 2014). However, the Cengkrong mangrove area has no conflict management mechanism. The availability of conflict handling mechanisms through collaboration between local governments and community monitoring groups is expected to resolve conflicts of interest. Institutional reinforcement through strengthening relationships between local government and community monitoring groups can enhance the implementation of sanctions for communities that damage or change the function of mangrove land so that it has a deterrent effect for actors. The activeness of the mangrove ecosystem management agency affects the sustainability of the mangrove ecosystem. Although the community watch group began in 2008 to actively rehabilitate and develop mangrove areas into ecotourism, the local government's support will further strengthen public awareness of the importance of mangroves for life. Furthermore, the openness between the two parties is also expected to enhance institutions and management to minimize damage to the mangrove ecosystem. 
Community-based mangrove management strategies through persuasive strategies are carried out in the form of coaching; educational strategy carried out in the way of training and facilitative strategy in the form of providing business assistance which is one of the efforts in increasing community participation in mangrove rehabilitation (Turisno et al., 2018).

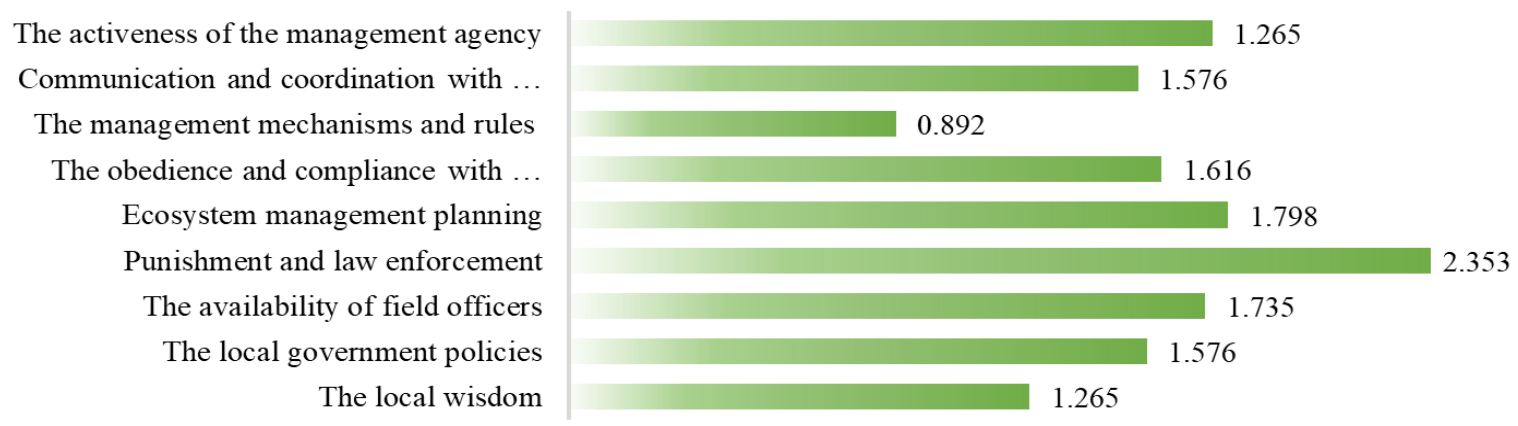

Figure 6. Leverage scoring for law and institution dimension

Figure 7 provides information on leverage scoring for the technology dimension. Based on the figure, the sensitive indicators which are the critical dimension of technology concern are solid waste management technology, availability of electricity supply, and mangrove seed nurseries. The development of mangrove ecotourism areas was using an environmentally friendly technology. The bridge-building that crosses the mangrove area is made of wood raw material and does not damage the mangrove. Tourism activities cause the impact of environmental pollution in the form of solid and liquid waste if there are no procedures or regulations to visit Cengkrong ecotourism. Tourism activities in the Cengkrong mangrove produce wastewater from households and plastic waste that has not been appropriately managed. Waste that is not appropriately managed will impact environmental pollution and affect the cleanliness and comfort of tourist areas (Dewi, 2017). A recycling process can do organic waste processing. This process aims to produce a variety of new products in the form of bags, wallets, doormats, decorative lamps, photo frames, and various other handicraft products while processing organic waste into compost and biogas through the making of biodigesters. The remaining untreated organic and inorganic waste can be further processed using an incinerator. With proper waste management, it is expected that electricity needs in the area can be met. It is caused by the high electricity demand that must be paid when using an electricity company. Apart from processing waste, appropriate technology can also be applied through solar power to improve safety and tourism at night. According to Hayat et al (2018), solar energy is environmentally friendly energy that is renewable as future energy and free of pollution so that the negative impact on the environment is minimal. Evaluation of mangrove rehabilitation's causes is not successful. It is the lack of mastery of rehabilitation technology, as well as the absence of periodic monitoring and maintenance of seedlings that have been planted (Mukhlisi et al., 2014). Although the community watch group has the expertise to plant mangrove trees, they need technology to accelerate mangrove growth. Plasma technology accelerates seed growth by $43 \%$, and the hatching time has been cut to 2.4 months to minimize costs, maintenance personnel, and increase community profits (Nur et al., 2013).

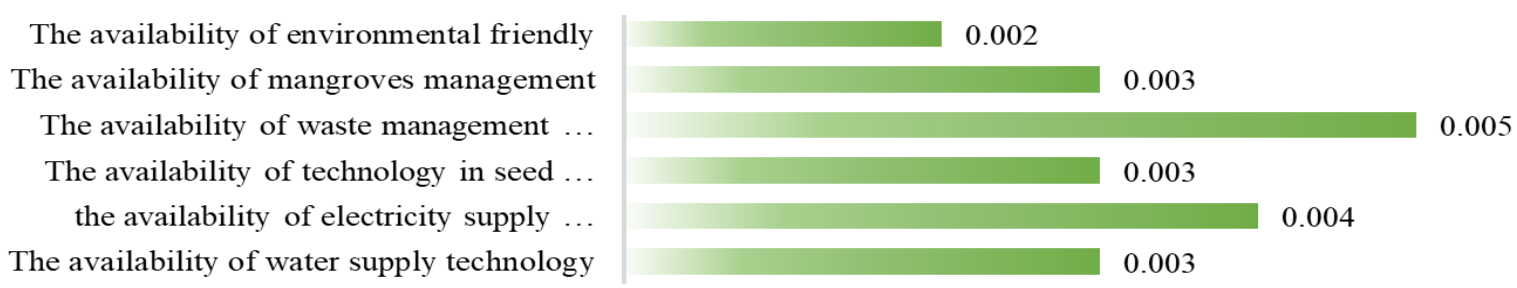

Figure 7. Leverage scoring for technology dimension

The management of mangroves in Cengkrong in improving sustainability should pay attention to the economic, social, and technological dimensions, primarily social because it has the lowest value of sustainability index. Also, the ecological dimension, which has the highest sustainability index to maintain by maintaining environmental pollution, does not occur. Furthermore, Cengkrong Beach Mangrove ecotourism community awareness is an indicator of the sustainability of mangrove ecosystems. The primary cause of damage to the mangrove area is the low level of coastal community knowledge about mangroves' functions and benefits. Then, the uncertainty of mangrove management rights that causes conflicts of use that requires conflict handling. Moreover, the management must disclose factual data about the implementation of mangrove ecosystems to the local government so that transparency about the accuracy of the data on the contribution and benefits of mangroves can be known by all parties involved. This is because this area requires grants made by the community and local government to create a database in accordance with Law No. 27 of 2007. The latest data can be considered to increase production or use mangrove resources to provide livelihood opportunities. Another problem in the area that has not yet been resolved is the potential of waste from tourist activities that are not properly regulated to produce pollution in order to minimize the need for waste management technology (Siringo et al., 2020). The hope is that the potential of treated waste can meet the electricity needs using solar technology at Cengkrong Beach Mangrove ecotourism for lighting at night at low cost with the aim of developing investment and security. The positive thing that has been done by the manager is that the development of job opportunities can be done through counseling and training to improve the skills and abilities of the 
community which gives an increase in the income increase. In addition, the manager initiated a mangrove nursery to provide benefits for extensive mangrove development in the Cengkrong Beach Mangrove ecotourism.

\section{Proposed institutional reinforcement model}

In general, mangrove ecotourism in Cengkrong shows a modest performance in five sustainability relationships. Law and institutions are the highest values in the mangrove ecotourism sustainability performance (Figure 2). The government, through the Department of Marine and Fisheries, has over the region bypassing several regulations. Among the regulations issued in the management of the Cengkrong coastal mangrove, which are regulated under Law No. 41 of 1999 (Forestry), Law No. 26 of 2007 (Spatial Planning), Law No. 45 of 2009 (Fisheries), Law No. 32 of 2009 (Environmental Protection and Management), and Law No. 01 of 2014 (Management of Coastal Areas and Small Islands). The regulation was established to preserve the mangrove forest ecosystem. Additionally, a community monitoring group was formed to carry out management and preserve the mangroves of the coastal area. Furthermore, there is substantial room for improvement to the 'sustainability' category via more effective interaction with stakeholders and resolving the negative impact each party may have caused the other. To ensure that ecotourism activities are sustainable, pro-poor, and improve the sustainability relationship with the community (Cobbinah et al., 2017; Rivera and Gutierrez, 2018), it is necessary for foster linkages between the different stakeholders (Government agencies and tourist, community monitoring group). It aims to form partnerships with private actors and stimulate the local economy, promote integration and active involvement of local communities, and emphasize sustainability, taking into account environmental and socioeconomic factors (Cobbinah, 2015). The integration of local communities and local governments in this institutional reinforcement through active participation. With this action, the effect of threatening tourism brought to the conservation of the environment can be minimized if tourists, local communities, and government agencies, including community monitoring groups, play their roles accordingly. First, strengthen relationships between government agencies and community monitoring groups for strict enforcement of laws and regulations, including restricting the mangrove ecotourism capacity, increasing the number of staff/officers on duty, and raising the financial transparency between both parties. Second, residents and operators should educate tourists on appropriate activities when in the mangrove ecotourism to reduce any negative impact on the mangrove's ecosystem and actively get the tourists involved in conservation work. Lastly, tourists should play their roles as responsible visitors, not to pollute the mangrove area, and fully follow the tracks suggested by operators. Therefore, there are several points to make a model in institutional reinforcement, first, providing decisions about the clarity of boundaries so that everyone is easy to identify and know it. Second, making rules in line with local conditions is marked by the existence of appropriate regulations for the benefit of resource conservation, protection of the local economy, strengthening social systems, and easy enforcement and monitoring. Third, arranging and managing rules by the community in the form of prohibition of mangrove crab capture, the prohibition of picking mangrove plants, the prohibition of littering. Fourth, strengthening local institutions in managing ecotourism.

Fifth, choosing supervisors who are respected by the community, marked by the community having its instruments and mechanisms of supervision with supervisory actors who have the community's legitimacy. Sixth, imposing punishment can be applied in mangrove ecotourism if violations occur, including social, administrative, and economic punishment. If there are violations known by the community, the community will report to the head of the community monitoring watch and the village head to impose punishment. Sanctions are given by the head of the village, which has a bundle of power in the form of authority over the village. The punishment was in the way of community service to clean the mangrove area for one day, fines, to more severe punishment in the form of eviction. In addition, it is related to a formal conflict resolution mechanism. Conflicts that occur after the development of ecotourism management are in the form of land conflicts. Unclear boundaries and the absence of land certificates encourage land conflicts. Land conflicts have occurred in the form of recognition of land management rights between community monitoring watch and the Forest Department in the area. The resolution of this land conflict will be achieved if the community monitoring watch is willing to work together and establish open relations with the local government to manage the mangrove area stronger than legally. Furthermore, strengthening recognition from the government could be in the form of law and regulation. Lastly, strengthening bridging social capital with the university and linking social capital with the private sector.

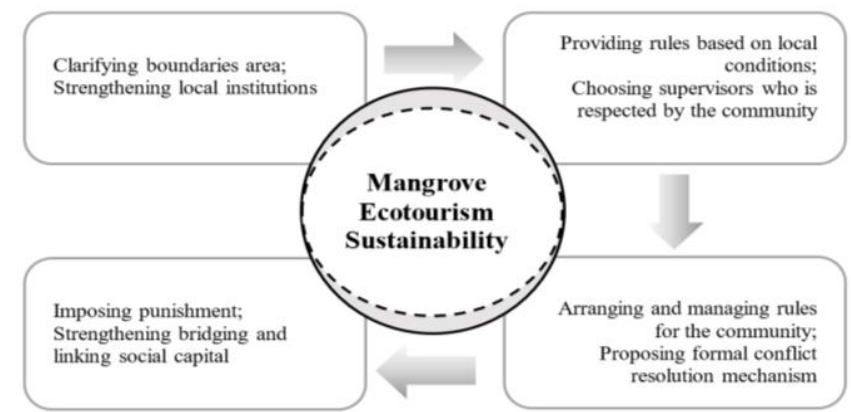

Figure 8. The Institutional reinforcement model in mangrove ecotourism sustainability
Moreover, institutional reinforcement is provided in Figure 8 , it is hoped that there will be institutional strengthening that will make the community more motivated to protect the mangrove forest so that the social dimension will increase. Therefore, institutional reinforcement supports two theories that explain the relationship between ecotourism and conservation. First, ecotourism produces preservation; the local community must feel the economic benefits. Besides, another theory holds that apart from economic benefits, social benefits must be present (Salafsky and Wollenberg, 2000; Stronza and Pegas, 2008). Existing theories identify tourism revenues as a critical component in ensuring that ecotourism results in environmental conservation.

\section{CONCLUSION}

This study pays attention to the stakeholder approach sustainability assessment. It presents the process of assessing the ecotourism sustainability of Cengkrong Beach Mangrove using the MDSR-ecotourism framework. Overall, Cengkrong Beach Mangrove achieved a sustainability level of 76.20 percent and performed moderately on five indicators (ecology, economy, 
social, law and institutional, and technology). The highest dimension is ecology due to the minimum level of pollution in the area. Even Cengkrong beach mangrove is a tourist destination potentially polluted by the tourist; however, the area is not densely populated. Therefore, no pollution is caused by excess industrial waste. If this condition can be maintained, the mangroves area will work to prevent stream erosion. The dimension that must be considered is social due to its lowest index. The social dimension in mangrove management is community awareness, community knowledge and perception, and conflict handling mechanisms. To strengthen the social dimension, it requires reinforcement in the institution in mangrove ecotourism. Therefore, it is necessary to establish collaborative management among all stakeholders with a fair distribution of benefits. Besides, skills training and socialization of ecotourism management are needed to view the governance of relations between stakeholders. With the role of good governance, policy integration mechanisms are required in terms of vertical and horizontal coordination; local communities can access transparent public consultation and the involvement of sustainable management. As the scoring was done by experts' judgments based on reports from the region and their personal experiences, it did not necessarily need new quantitative data for the attributes, although the analysis would definitely benefit from that.

Indeed, for robust management advice, new quantitative data from the field are beneficial. Further empirical research to improve the accuracy of the attribute scores is required. Nevertheless, this preliminary research result can be used to improve mangrove ecotourism Pancer Cengkrong management and identify characteristics of the mangrove ecosystem and the society to measure in the field. This information provides crucial guideline where financial, human and institutional resources for mangrove ecosystem are very limited, as in the Pancer Cengkrong. This study has a limitation in measuring the effectiveness of community management to maintain resource use and livelihood support. Notwithstanding this limitation, the study suggests for further research to involve evaluation and development research to gain more comprehensive findings.

\section{REFERENCES}

Agusalim, A., \& Hartoni, (2014). The potential of mangrove suitability as an ecotourism area on the coast of the Musi river estuary, Banyuasin Regency (Indonesian Origin). Maspari Journal of Marine Science Research, 6(2), 148-156. https://doi.org/10.36706/maspari.v6i2.3037

Alam, M., Furukawa, Y., \& Akter, S. (2010). Forest-based tourism in Bangladesh: status, problems, and prospects. Tourismos, 5(1), 163-172. Anggoro, S., Purwanti, F., \& Gunawan, B.I. (2019). Strategies for sustainable ecotourism development in the marine waters of Bontang City, Indonesia. Aquaculture, Aquarium, Conservation \& Legislation, 12(5), 1779-1787.

Aulia, F., Badaruddin, R., \& Utomo, B. (2020). Local Knowledge of North Sumatera Coastal Communities on Sustainable Mangroves Identification and Types. Journal of Southwest Jiaotong University, 55(3). https://doi.org/10.35741/issn.0258-2724.55.3.45

Abdullah, K., Said, A.M., \& Omar, D. (2014). Community-Based Conservation in Managing Mangrove Rehabilitation in Perak and Selangor. Procedia - Social and Behavioral Sciences 153:121 - 131. https://doi.org/10.1016/i.sbspro.2014.10.047

Barbier, E.B., Hacker, S.D., Kennedy, C., Koch, E.W., Stier, A.C., \& Silliman, B.R. (2011). The value of estuarine and coastal ecosystem services. Ecological monographs, 81(2), 169-193. https://doi.org/10.1890/10-1510.1

Carandang, A.P., Camacho, L.D., Gevaña, D.T., Dizon, J.T., Camacho, S.C., de Luna, C.C., Puhlin, B.P., Combalicer, E.A., Paras, E.D., Peras, R.J.J., \& Rebugio, L.L. (2013). Economic valuation for sustainable mangrove ecosystems management in Bohol and Palawan, Philippines. Forest science and technology, 9(3), 118-125. https://doi.org/10.1080/21580103.2013.801149

Cesario, A.E., Yuwono, S.B., \& Ourniati, R. (2015). Participation of community groups in preserving mangrove forests in Margasari Village, Labuhan Maringgai District, East Lampung Regency (Indonesian origin). Jurnal Sylva Lestari, 3(2), 21-30. http://dx.doi.org/10.23960/is12321-30

Cobbinah, P.B. (2015). Contextualising the meaning of ecotourism. Tourism Management Perspectives, 16, 179-189. https:/doi.org/10.1016/i.tmp.2015. 07.015

Cobbinah, P.B., Amenuvor, D., Black, R., \& Peprah, C. (2017). Ecotourism in the Kakum Conservation Area, Ghana: Local politics, practice and outcome. Journal of Outdoor Recreation and Tourism, 20, 34-44. https://doi.org/10.1016/i.iort.2017.09.003

Cormier-Salem, M.C., \& Panfili, J. (2016). Mangrove reforestation: greening or grabbing coastal zones and deltas? Case studies in Senegal. African Journal of Aquatic Science, 41(1), 89-98. https://doi.org/10.2989/16085914.2016.1146122

Das, M., \& Chatteriee, B. (2015). Ecotourism: A panacea or a predicament? Tourism Management Perspectives, 14, 3-16. https://doi.org/10.1016/j.tmp.2015.01.002

Dewi, R.P. (2017). Waste management system design to support the development of creative industries in tourism areas (in Indonesian). Prosiding Sendi, 217-221.

Donato, D.C., Kauffman, J.B., Murdiyarso, D., Kurnianto, S., Stidham, M., \& Kanninen, M. (2011). Mangroves among the most carbon-rich forests in the tropics. Nature geoscience, 4(5), 293-297. https://doi.org/10.1038/ngeo1 123

Eddy, S., Ridho, M.R., Iskandar, I., \& Mulyana, A. (2017). Community-based mangrove forests conservation for sustainable fisheries. Jurnal Silvikultur Tropika, 7(3), 42-47. https://doi.org/10.31219/osf.io/x659w

Feagin, R.A., Mukheriee, N., Shanker, K., Baird, A.H., Cinner, J., Kerr, A.M., \& Lo Seen, D. (2010). Shelter from the storm? Use and misuse of coastal vegetation bioshields for managing natural disasters. Conservation Letters, 3(1), 1-11. https://doi.org/10.1111/j.1755-263X.2009.00087.x

Friess, D.A. (2017). Ecotourism as a tool for mangrove conservation. Sumatra Journal of Disaster, Geography and Geography Education, 1(1), 24-35. http://sjdgge.ppi.unp.ac.id/index.php/Sidgge/article/view/32

Ghazoul, J. (2007). Recognising the complexities of ecosystem management and the ecosystem service concept. Gaia-Ecological Perspectives for Science and Society, 16(3), 215-221. https://doi.org/10.14512/gaia.16.3.13

Ghorbani, A., Raufirad, V., Rafiaani, P., \& Azadi, H. (2015). Ecotourism sustainable development strategies using SWOT and QSPM model: A case study of Kaji Namakzar Wetland, South Khorasan Province, Iran. Tourism Management Perspectives, 16, $290-297$. https://doi.org/10.1016/i.tmp.2015.09.005

Giri, C., Ochieng, E., Tieszen, L.L., Zhu, Z., Singh, A., Loveland, T., Masek, J., \& Duke, N. (2011). Status and distribution of mangrove forests of the world using earth observation satellite data. Global Ecology and Biogeography, 20(1), 154-159. https://doi.org/10.1111/i.1466-8238.2010.00584

Hamilton, S.E., \& Casev, D. (2016). Creation of a high spatio-temporal resolution global database of continuous mangrove forest cover for the $21^{\text {st }}$ century (CGMFC-21). Global Ecology and Biogeography, 25(6), 729-738. https://doi.org/10.1111/geb.12449

Hayat, M.B., Ali, D., Monvake, K.C., Alagha, L., \& Niaz, A. (2018). Solar energy-A look into power generation, challenges, and a solar-powered future. International Journal of Energy Research, 43(3), 1049-1067. https://doi.org/10.1002/er.4252

Karlina, E., Kusmana, C., Marimin, M., \& Bismark, M. (2016). Analysis of the Sustainability of Mangrove Protected Forest Management in Batu Ampar, Kubu Raya District, West Kalimantan Province (In Indonesian). Jurnal Analisis Kebijakan Kehutanan, 13(3), $201-219$. https://doi.org/10.20886/iakk.2016.13.3.201-219

Lee, S.Y., Primavera, J.H., Dahdouh-Guebas, F., McKee, K., Bosire, J.O., Cannicci, S., Diele, K., Fromard, F., Koedam, N., Marchand, C., Mendelsshon, I., Mukherjee, N., \& Record, S. (2014). Ecological role and services of tropical mangrove ecosystems: a reassessment. Global ecology and biogeography, 23(7), 726-743. https://doi.org/10.1111/geb.12155 
Lin, M.C., \& Yang, M.W. (2016). Environmental and social impact assessment for the tourism industry: a case study of coastal recreation areas in Hualien Taiwan. Advances in Management and Applied Economics, 6(6), 29-47. http://www.scienpress.com/Upload/AMAE\%2Fvol\%206 6_3.pdf

Martínez-Espinosa, C., Wolfs, P., Velde, K.V., Satyanarayana, B., Dahdouh-Guebas, F., \& Huge, J. (2020). Call for a collaborative management at Matang Mangrove Forest Reserve, Malaysia: An assessment from local stakeholders' view point. Forest Ecology and Management, 458, 1-14. https://doi.org/10.1016/i.foreco.2019.117741

Mitchell, J., \& Faal, J. (2007). Holiday package tourism and the poor in the Gambia. Development Southern Africa, 24(3), 445-464. https://doi.org/10.1080/03768350701445541

Mukhlisi, M., Hendrarto, I.B., \& Purnaweni, H. (2014). Sustainability Status of Mangrove Forest Management in Sidodadi Village, Padang Cermin District, Pesawaran Regency, Lampung Province (In Indonesian). Jurnal Geografi: Media Informasi Pengembangan dan Profesi Kegeografian, 11(1), 58-70. https://doi.org/10.15294/jg.v11i1.8040

Muluk. (2010). Pengelolaan Ekosistem Mangrove oleh Masyarakat Pesisir. Jurnal Ilmu Lingkungan. 1(2), 24-35.

Mumby, P.J., Edwards, A.J., Arias-González, J.E., Lindeman, K.C., Blackwell, P.G., Gall, A., \& Wabnitz, C.C. (2004). Mangroves enhance the biomass of coral reef fish communities in the Caribbean. Nature, 427(6974), 533-536.

Nur M., Nasruddin, Jafron W. dan Sumariyah. 2013. Penerapan Teknologi Plasma untuk Mempercepat Persemaian Mangrove Sebagai Upaya Rehabilitasi Green Belt untuk Mengatasi Abrasi. Riptek, 7(1), 15-26. https://www.researchgate.net/profile/Muhammad-Nur6/publication/334130480_PENERAPAN_TEKNOLOGI_PLASMA_UNTUK_MEMPERCEPAT_PERSEMAIAN_MANGROVE_SEB AGAI_UPAYA_REHABILITASI_GREEN_BELT_UNTUK_MENGATASI_ABRASI/links/5d199c96299bf1547c8ce5f7/PENERAPA N-TEKNOLOGI-PLASMA-UNTUK-MEMPERCEPAT-PERSEMAIAN-MANGROVE-SEBAGAI-UPAYA-REHABILITASI-GREE N-BELT-UNTUK-MENGATASI-ABRASI.pdf

Nguyen, T., Tong, V., Quoi, L., \& Parnell, K. (2016). Mangrove Restoration: Establishment Of A Mangrove Nursery On Acid Sulphate Soils. Journal of Tropical Forest Science, 28(3), 275-284. Retrieved February 6, 2021, from http://www.jstor.org/stable/43856532

Phelan, A., Ruhanen, L., \& Mair, J. (2020). Ecosystem services approach for community-based ecotourism: towards an equitable and sustainable blue economy. Journal of Sustainable Tourism, 28:10, 1665-1685, https://doi.org/10.1080/09669582.2020.1747475

Pitcher, T.J., \& Preikshot, D. (2001). RAPFISH: a rapid appraisal technique to evaluate the sustainability status of fisheries. Fisheries Research, 49(3), 255-270. https://doi.org/10.1016/S0165-7836(00)00205-8

Pitcher, T.J., Lam, M.E., Ainsworth, C., Martindale, A., Nakamura, K., Perry, R.I., \& Ward, T. (2013). Improvements to Rapfish: a rapid evaluation technique for fisheries integrating ecological and human dimensionsa. Journal of Fish Biology, 83(4), 865-889. https://doi.org/10.1111/jfb.12122

Purwanti, P., Susilo, E., \& Indrayani, E. (2017a). Household economic activities of coastal resource users' community in cengkrong coastal area, Prigi Bay, Trenggalek District. Russian Journal of Agricultural and Socio-Economic Sciences, 62, 91-99. https://doi.org/10.18551/rjoas.2017-02.11

Purwanti, P., Susilo, E., \& Indrayani, E. (2017c). Sustainable mangrove forest management: an institutional approach and economic incentives (In Indonesian). Universitas Brawijaya Press (UB Press).

Purwanti, P., Susilo, E., \& Lestariadi, R.A. (2017). Mangrove Forest Management and Mangrove-Based Business Development Opportunities in the Gulf of Prigi Trenggalek. International Journal of Social and Local Economic Governance, 3(2), 62-68. ISSN e2477-1929. Accessed: 06 feb. 2021. https://ijleg.ub.ac.id/index.php/ijleg/article/view/71

Richards, D.R., \& Friess, D.A. (2016). Rates and drivers of mangrove deforestation in Southeast Asia, 2000-2012. Proceedings of the National Academy of Sciences, 113(2), 344-349. https://doi.org/10.1073/pnas.1510272113

Rivera, J.P.R., \& Gutierrez, E.L.M. (2019). A framework toward sustainable ecotourism value chain in the Philippines. Journal of Quality Assurance in Hospitality \& Tourism, 20(2), 123-142. https://doi.org/10.1080/1528008X.2018.1492495

Rudianto, R., Bengen, D.G., \& Kurniawan, F. (2020). Causes and Effects of Mangrove Ecosystem Damage on Carbon Stocks and Absorption in East Java, Indonesia. Sustainability, 12(24):10319. https://doi.org/10.3390/su122410319

Salafsky, N., \& Wollenberg, E. (2000). Linking livelihoods and conservation: a conceptual frame work and scale for assessing the integration of human needs and biodiversity. World development, 28(8), 1421-1438. https://doi.org/10.1016/S0305-750X(00)00031-0

Santos, L.C.M., Gasalla, M.A., Dahdouh-Guebas, F., Bitencourt, M.D., 2017. Socio-ecological assessment for environmental planning in coastal fishery areas: A case study in Brazilian mangroves. Ocean Coast. Manag. 138, 60-69. https://doi.org/10.1016/j. ocecoaman.2017.01.009.

Satyanarayana, B., Mulder, S., Jayatissa, L.P., \& Dahdouh-Guebas, F. (2013). Are the mangroves in the Galle-Unawatuna area (Sri Lanka) at risk? A social-ecological approach involving local stakeholders for a better conservation policy. Ocean \& coastal management, $71,225-$ 237. https://doi.org/10.1016/i.ocecoaman.2012.10.008

Siringo, R., Herdiansyah, H., \& Kusumastuti, R.D. (2020). Underlying factors behind the low participation rate in electronic waste recycling. Global Journal of Environmental Science and Management, 6(2), 203-214. https://doi.org/10.22034/GJESM.2020.02.06

Sodikin (2014). Perception of pond farmer communities on the preservation of mangrove forests in Pabean Ilir Village, Pasekan District, Indramayu Regency (in Indonesian). Jurnal Geografi Gea, 12(1), 40-48. https://doi.org/10.17509/gea.v12i1.2597

Stone, M.T., \& Rogerson, C.M. (2015). Community-based natural resource management and tourism: Nata bird sanctuary, Botswana. Tourism Review International, 15(1-2), 159-169. https://doi.org/10.3727/154427211X13139345020570

Stronza, A., \& Pêgas, F. (2008). Ecotourism and conservation: Two cases from Brazil and Peru. Human Dimensions of Wildlife, 13(4), 263279. https://doi.org/10.1080/10871200802187097

Sueb, S., Suhadi, S., Suwarni, S., Diartika, E., \& Rizky, N. (2020). Souvenir entrepreneurship based on local potential for the development of mangrove ecotourism in Cengkrong Trenggalek (In Indonesian). Jurnal Graha Pengabdian, 2(1), 47-55. http://journal2.um.ac.id/ index.php/igp/article/view/12156

Suwanno, S., Tongsanoer, N., Suwanno, N., \& Phongchiewboon, A. (2017). Potential of Ecological Resources and Ecotourism Destination Management: A Case Study in Koh-Mak Community, Southern Thailand. PSAKU International Journal of Interdisciplinary Research, 6(2), 9-21.

Thompson, B.S., Gillen, J., \& Friess, D.A. (2018). Challenging the principles of ecotourism: insights from entrepreneurs on environmental and economic sustainability in Langkawi, Malaysia. Journal of Sustainable Tourism, 26(2), 257-276. https://doi.org/10.1080/09669582.2017.1343338

Turisno, B.E., Suharto, R., \& Priyono, E.A. (2018). Community participation and government authority in mangrove conservation as an effort to prevent tidal flooding and as a tourist spot (in Indonesian). Masalah-Masalah Hukum, 47(4), 479-497.

Wibowo A.B., Sutrisno A. dan Bambang Y. 2015. Status Keberlanjutan Dimensi Ekologi Dalam Pengembangan Kawasan Minapolitan Berkelanjutan Berbasis Perikanan Budidaya Air Tawar Di Kabupaten Magelang. Jurnal Saintek Perikanan, 10(2), $107-113$. https://doi.org/10.14710/iifst.10.2.107-113

Young, J.C., Rose, D.C., Mumby, H.S., Benitez-Capistros, F., Derrick, C.J., Finch, T., Garcia, C., Home, C., Marwaha, E., Morgans, C., Parkinson, S., Shah, J., Wilson, K.A., \& Mukherjee, N. (2018). A methodological guide to using and reporting on interviews in conservation science research. Methods in Ecology and Evolution, 9(1), 10-19. https://doi.org/10.1111/2041-210X.12828 